\title{
PENGARUH GENDER, GAYA KEPEMIMPINAN DAN BUDAYA ORGANISASI TERHADAP KINERJA KARYAWAN (STUDI KASUS PADA PT XYZ)
}

\author{
Jenia Nur Soelistyoningrum \\ Program Studi Magister Manajemen Universitas Tarumanagara \\ jeniasoelistyoningrum@yahoo.com
}

Masuk : 28-11-2017, revisi : 20-12-2017 diterima untuk diterbitkan : 20-12-2017

\begin{abstract}
The purpose of this emprical study is to analyze the effect of gender, leadership style and organization culture to the performance of employee. The research samples consist of 80 respondents. This research uses primary data that obtained by distributing questionnaires to PT XYZ employees who meet the criteria that have been determined through purposive sampling. This research uses multiple linear regression analysis. The results show that gender, leadership style and organization culture positively influence the performance of employee.
\end{abstract}

Keywords: Gender, Leadership Style, Organization Culture, Performance of Employee

\section{PENDAHULUAN}

Perkembangan bisnis di industri pembiayaan semakin cepat dari tahun ke tahun. Semakin banyak bermunculan pesaing-pesaing baru maka akan semakin berdampak pada kemampuan suatu perusahaan dalam menghadapi tantangan di masa mendatang. Oleh sebab itu dibutuhkan sumber daya manusia yang mumpuni untuk dapat menjawab tantangan perusahaan di masa datang. Sumber daya manusia yang cakap dan berkualitas dapat dimanfaatkan sebagai modal perusahaan.

Seiring majunya perkembangan suatu zaman maka akan semakin merubah cara pandang masyarakat dan organisasi dalam melihat gender. Gender adalah perbedaan yang terlihat antara laki-laki dan perempuan berdasarkan nilainya (Marmawi,2009 dalam Sabrina dan Sari, 2013). Gender diartikan sebagai perbedaan antara laki-laki dan perempuan. Dari perbedaan ini, munculah karakteristik seorang pemimpin yang dipengaruhi oleh gender, misalnya pemimpin laki-laki dan pemimpin perempuan memiliki sifat kepemimpinan yang berbeda yang dipengaruhi oleh perbedaan gender tersebut. Persoalan gender masih hangat diperbincangkan oleh berbagai pihak, dimana kepemimpinan suatu organisasi lebih banyak diambil alih oleh laki-laki daripada perempuan. Menurut koran Sindo edisi Maret 2016, Indonesia menempati urutan ke 6 di dunia dalam jumlah pemimpin atau CEO perempuan terbanyak (riset lembaga konsultan bisnis Grant Thornton).

Keberhasilan atau kegagalan suatu organisasi baik yang berorientasi bisnis maupun publik, biasanya dipersepsikan sebagai keberhasilan atau kegagalan pemimpin. Peran kepemimpinan yang sangat strategis dan penting bagi pencapaian misi, visi dan tujuan suatu organisasi, merupakan salah satu motif yang mendorong manusia untuk selalu menyelidiki seluk-beluk yang terkait dengan kepemimpinan. Budaya organisasi adalah sistem makna, nilainilai dan kepercayaan yang dianut bersama dalam suatu organisasi yang menjadi rujukan untuk bertindak dan membedakan organisasi satu dengan organisasi lain. Sehingga diharapkan akan berdampak terhadap kinerja karyawan. Kinerja juga merupakan hasil kerja yang dihasilkan atau disumbangkan seorang karyawan yang berkaitan dengan tugas dan tanggung jawab kepada perusahaan (Mangkunegara, 2010:13). Menurut Bass (1990) dalam Raharjo (2006), peran kepemimpinan atasan dalam memberikan kontribusi pada karyawan untuk pencapaian kinerja yang optimal dilakukan melalui lima cara yaitu: (1) pemimpin mengklarifikasi apa yang diharapkan dari karyawan, secara khusus tujuan dan sasaran dari kinerja mereka, (2) pemimpin menjelaskan bagaimana memenuhi harapan tersebut, (3) pemimpin mengemukakan kriteria dalam melakukan evaluasi dari kinerja secara efektif, (4) pemimpin memberikan umpan balik 
ketika karyawan telah mencapai sasaran, dan (5) pemimpin mengalokasikan imbalan berdasarkan hasil yang telah mereka capai.

PT XYZ adalah salah satu perusahaan pembiayaan yang terkemuka di Indonesia. PT XYZ memiliki hampir 60 cabang yang tersebar di seluruh Indonesia. Sebagai anak perusahaan dari Trakindo Grup, PT XYZ dipimpin oleh 4 direksi yaitu Presiden Direktur, Wakil Presiden Direktur, Direktur Keuangan dan Direktur Operasional. Puncuk kepemimpinan di PT XYZ diambil oleh perempuan dan dibantu oleh 3 orang laki-laki sebagai pendukungnya. Hal ini sejalan dengan besarnya persentase jumlah karyawan laki-laki yang lebih besar daripada karyawan perempuan, dimana untuk karyawan dikantor pusat sendiri jumlah karyawan lakilaki mencapai persentase lebih dari $51 \%$ sedangkan jumlah karyawan perempuan memiliki jumlah persentase sebesar $49 \%$. Dengan komposisi tersebut maka dapat dijelaskan bahwa gaya kepemimpinan antara pemimpin perempuan dengan laki-laki berbeda. Adanya perbedaan gaya kepemimpinan, maka akan berpengaruh terhadap keputusan-keputusan yang diambil. Salah satunya adalah keputusan dalam penentuan pemberian kompensasi kepada para karyawan.

\section{TELAAH KEPUSTAKAAN Gender}

Secara umum, pengertian gender adalah perbedaan yang tampak antara laki-laki dan perempuan apabila dilihat dari nilai dan tingkah laku. Gender dalam pengertian ilmu social diartikan sebagai pola relasi laki-laki dan perempuan yang didasarkan pada ciri social masingmasing. Tercakup didalamnya pembagian kerja, kuasa, perilaku, peralatan, bahasa, persepsi yang membedakan lelaki dan perempuan dan banyak lagi.

Di Indonesia sendiri perbedaan gender masih menjadi perbincangan. Sebagai penganut paham patriakis dimana peran laki-laki lebih unggul daripada peran perempuan, menjadi suatu hal lumrah jika hampir sebagian besar posisi puncak diisi oleh laki-laki. Tawney (1931) menyebutkan bahwa keragaman peran apakah karena faktor biologis, etnis, aspirasi, minat, pilihan, atau budaya pada hakikatnya adalah realita kehidupan manusia. Hubungan laki - laki dan perempuan bukan dilandasi konflik dikotomis, bukan pula struktural fungsional, tetapi lebih dilandasi kebutuhan kebersamaan guna membangun kemitraan yang hamonis, karena setiap pihak memiliki kelebihan sekaligus kelemahan yang perlu diisi dan dilengkapi pihak lain dalam kerjasama yang setara.

$\mathrm{Ha}_{1}$ : Gender berpengaruh positif terhadap kinerja karyawan.

\section{Gaya Kepemimpinan}

Gaya kepemimpinan adalah pola tingkah laku yang dirancang sedemikian rupa untuk mempengaruhi bawahannya agar dapat memaksimalkan kinerja yang dimiliki bawahannya sehingga kinerja organisasi dan tujuan organisasi dapat dimaksimalkan. Setiap pemimpin pada dasarnya memiliki perilaku yang berbeda dalam memimpin bawahannya, perilaku tersebut disebut dengan gaya kepemimpinan. Gaya kepemimpinan merupakan suatu cara pemimpin untuk mempengaruhi bawahannya yang dinyatakan dalam bentuk pola tingkah laku atau kepribadian.

Gaya kepemimpinan menurut Hasibuan (2005:205), dibagi menjadi lima yaitu Kepemimpinan otoriter adalah jika kekuasaan atau wewenang, sebagian besar mutlak tetap berada pada pimpinan atau menganut sistem sentralisasi wewenang. Pengambilan keputusan dan kebijaksanaan hanya ditetapkan sendiri oleh pemimpin, bawahan tidak diikutsertakan untuk memberikan saran, ide dan pertimbangan dalam proses pengambilan keputusan. Kepemimpinan partisipatif adalah apabila dalam kepemimpinannya dilakukan dengan cara persuasive, menciptakan kerja sama yang serasi, menumbuhkan loyalitas, dan partisipasi para bawahan agar merasa ikut memiliki perusahaan. Kepemimpinan delegatif apabila seorang pemimpin mendelegasikan wewenang kepada bawahan dengan agak lengkap. Dengan demikian, bawahan dapat mengambil keputusan dan kebijaksanaan dengan bebas atau leluasa dalam melaksanakan pekerjaan. Kepemimpinan Kharismatik ini memiliki daya tarik dan 
pembawaan yang luar biasa, sehingga ia mempunyai pengikut dan jumlahnya yang sangat luar biasa. Sampai sekarang pun orang tidak mengetahui sebab-sebab secara pasti mengapa seseorang itu memiliki kharisma yang begitu besar, dan yang terakhir adalah Kepemimpinan Demokratik dimana menitikberatkan pada bimbingan yang efisien pada para anggotanya. Koordinasi pekerjaan terjalin dengan baik dengan semua lini, terutama penekanan pada rasa tanggung jawab internal (pada diri sendiri) dan kerja sama yang baik.

$\mathrm{Ha}_{2}$ : Gaya kepemimpinan berpengaruh positif terhadap kinerja karyawan.

\section{Budaya Organisasi}

Budaya selalu melekat dalam kehidupan sehari-hari. Budaya tercipta tidak hanya dalam keluarga, organisasi maupun berbangsa dan bernegara. Budaya ini dapat membedakan masyarakat atau organisasi satu dengan yang lainnya dan dapat menjadikan ciri dari suatu masyarakat atau organisasi. Seiring berjalannya waktu, budaya dirasakan dapat memberikan kontribusi bagi efektivitas dan efiensi kerja suatu organisasi.

Menurut Drucker dalam Tika (2006) budaya organisasi adalah pokok penyelesaian masalah-masalah eksternal dan internal yang pelaksanaanya dilakukan secara konsisten oleh suatu kelompok yang kemudian diwariskan kepada anggota-anggota baru sebagai cara yang tepat untuk memahami, memikirkan dan merasakan terhadap masalah-masalah yang terkait. Penelitian Jennifer dan Bersade (1997) dalam Mariam (2009), mengambil sampel 102 perusahaan jasa di Amerika. Hasil temuan berkaitan dengan budaya organisasi kuat adalah: (1) Budaya organisasi yang kuat membantu kinerja organisasi bisnis karena menciptakan suatu tingkatan yang luar biasa dalam diri para karyawan; (2) Budaya organisasi yang kuat membantu kinerja organisasi karena memberikan struktur dan kontrol yang dibutuhkan tanpa harus bersandar pada birokrasi formal yang kaku dan yang dapat menekan tumbuhnya motivasi dan inovasi.

$\mathrm{Ha}_{3}$ : Budaya organisasi berpengaruh positif terhadap kinerja karyawan.

\section{Kinerja Karyawan}

Pengertian kinerja adalah hasil kerja secara kualitas dan kuantitas yang dicapai oleh seorang pegawai dalam melaksanakan tugasnya sesuai dengan tanggung jawab yang diberikan kepadanya". Untuk mencapai tujuan organisasi, tentunya karyawan dituntut untuk memaksimalkan kinerja yang dia miliki. Kinerja karyawan adalah hal yang penting untuk diperhatikan organisasi, karena dapat mempengaruhi tercapainya tujuan dan kemajuan organisasi dalam suatu persaingan global yang sering berubah. Indikator kinerja karyawan menurut Bernadine (dalam Mas'ud 2004) terdiri dari Indikator Kualitas yaitu Tingkat dimana hasil aktifitas yang dilakukan mendekati sempurna, dalam arti menyesuaikan beberapa cara ideal dari penampilan aktifitas ataupun memenuhi tujuan yang diharapkan dari suatu aktifitas, Indikator Kuantitas yaitu meliputi kemampuan menyelesaikan seluruh pekerjaan melebihi pekerjaan yang ditugaskan, Indikator Ketepatan Waktu yaitu Tingkat suatu aktifitas diselesaikan pada waktu awal yang diinginkan, dilihat dari sudut koordinasi dengan hasil output serta memaksimalkan waktu yang tersedia untuk aktifitas lain, Efektifitas yaitu Tingkat penggunaan sumber daya manusia organisasi dimaksimalkan dengan maksud menaikan keuntungan atau mengurangi kerugian dari setiap unit dalam penggunaan sumberdaya dan terakhir adalah Indikator Kemandirian yang berarti Tingkat dimana seorang karyawan dapat melakukan fungsi kerjanya tanpa minta bantuan bimbingan dari pengawas atau meminta turut campurnya pengawas untuk menghindari hasil yang merugikan.

\section{Kerangka Teori dan Hipotesis}

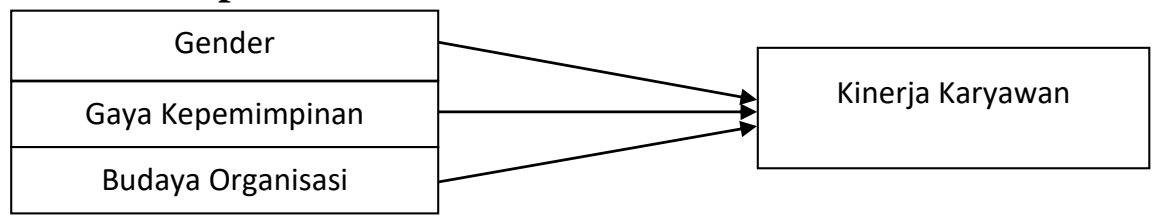

Gambar 1

Kerangka Teori dan Hipotesis 


\section{METODOLOGI PENELITIAN}

\section{Jenis \& Periode Penelitian}

Jenis penelitian yang dilakukan dalam penelitian ini penelitian kuantitatif. Periode penelitian dilakukan pada bulan Juli 2016 sampai dengan Juli 2017 dengan membagikan kuesioner kepada karyawan PT XYZ di kantor pusat. Hasil yang didapat dari kuesioner kemudian akan diolah dengan program SPSS.

\section{Sumber dan Pengumpulan Data}

Untuk memperoleh data dan informasi yang diperlukan dalam penelitian ini, maka akan dilakukan dengan data primer yaitu membagikan kuesioner kepada karyawan PT XYZ yang berjumlah 80 orang dan kemudian diukur dengan skala Likert. Sampel yang digunakan berdasarkan hasil dari proses seleksi sampel melalui purposive sampling.

\section{Variabel Penelitian}

Variabel penelitian ini terdiri dari empat variabel, yaitu satu variabel dependen dan tiga variabel independen. Variabel dependen dalam penelitian ini adalah kinerja karyawan, sedangkan variabel independen dalam penelitian ini adalah gender, gaya kepemimpinan dan budaya organisasi.

1. Variabel terikat (dependent variable)

Variabel terikat adalah variabel yang dikenai pengaruh atau diterangkan oleh variabel lain (Ghozali, 2006). Variabel terikat dalam penelitian ini adalah kinerja karyawan (Y).

2. Variabel bebas (independent variable)

Variabel bebas adalah suatu variabel yang fungsinya menerangkan (mempengaruhi) terhadap variabel lainnya (Ghozali, 2006). Variabel bebas dalam penelitian ini adalah gender (X1), gaya kepemimpinan (X2) dan budaya organisasi (X3).

\section{ANALISIS DAN BAHASAN TEMUAN Pengujian Validitas dan Reliabilitas}

Suatu kuesioner dikatakan valid jika pertanyaan pada kuesioner mampu mengungkapkan sesuatu yang akan diukur oleh kuesioner tersebut (Ghozali, 2006). Kriteria uji validitas yang digunakan adalah bila koefisien korelasi atau $r$ hitung $>r$ table maka dinyatakan valid. $R$ tabel dalam penelitian berada di angka 0,217, dengan nilai $r$ hitung untuk semua variabel berada diatas $r$ tabel. Sehingga dapat disimpulkan bahwa data yang digunakan valid.

Suatu kuesioner dikatakan reliabel dengan menggunakan perangkat lunak SPSS yaitu jika nilai Alpha Cronbach lebir besar dari 0,60. Uji reliabilitas dalam penelitian ini nilai Alpha Cronbach menunjukkan lebih besar dari 0,60 maka dapat dikatakan data reliabel. Detail pengujian reliabilitas untuk masing-masing variabel yaitu: Variabel Gender $(0,604)$, Variabel Gaya Kepemimpinan (0,797), Variabel Budaya Organisasi (0.817) dan Variabel Kinerja Karyawan (0,898).

\section{Subjek Penelitian}

Responden dalam penelitian ini terbagi menajdi dua yaitu laki-laki (51\%) dan perempuan (49\%) dengan status karyawan tetap dan masa bekerja mulai 1 sampai dengan 15 tahun. Tingkat pendidikan terakhir responden SLTA (1\%) / Diploma (15\%) / S1 (80\%) / S2 (4\%). 


\section{Uji Normalitas}

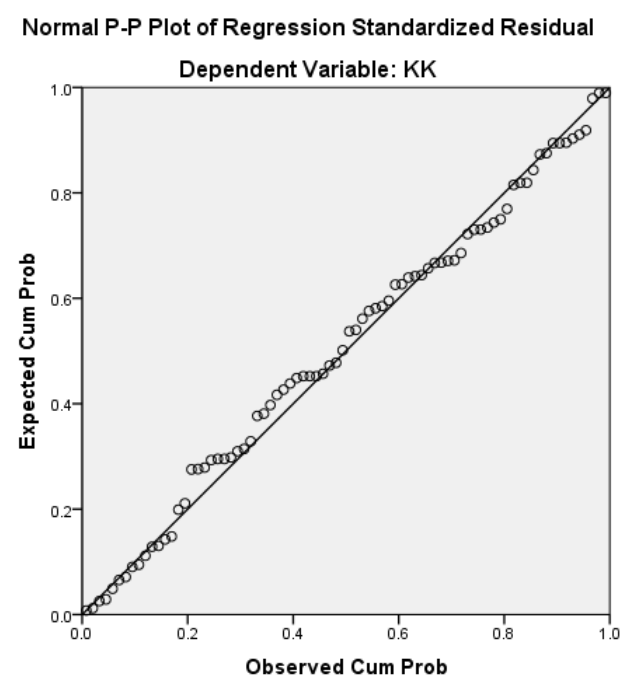

Gambar 2

Hasil Analisis Uji Normalitas

Uji normalitas digunakan untuk melihat normalitas pada model regresi. Metode yang digunakan untuk pengujian normalitas adalah dengan normal probability plot. Jika data (titik) menyebar di sekitar garis diagonal mengikuti arah garis diagonal atau grafik histogramnya menunjukkan pola distribusi normal, maka model regresi memenuhi asumsi normalitas. Dari hasil pengujian normalitas, dapat disimpulkan bahwa semua variabel menyebar diantara garis diagonal dan mengikuti arah garis diagonal tersebut. Sehingga dapat dinyatakan bahwa model regresi memenuhi asumsi normalitas.

\section{Uji Multikolinearitas}

Pengujian ini dapat dilakukan dengan melihat angka tolerance dan variance inflation factor (VIF). Dengan pengambilan keputusan jika ada variabel independen yang memiliki nilai tolerance $>0,10$ atau VIF $<10$, dapat disimpulkan bahwa tidak ada multikolenieritas antar variabel independen dalam model regresi. Nilai VIF untuk gender sebesar 1,034 dan nilai tolerance gender sebesar 0,967. Kemudian Nilai VIF untuk gaya kepemimpinan sebesar 1,414 dan nilai tolerance untuk gaya kepemimpinan sebesar 0,707. Selanjutnya nilai VIF untuk budaya organisasi sebesar 1,375 dan nilai tolerance untuk budaya organisasi sebesar 0,727. Terakhir nilai VIF untuk gender, gaya kepemimpinan dan budaya organisasi lebih kecil dari 10 serta nilai tolerance dari gender, gaya kepemimpinan dan budaya organisasi lebih dari 0,10 sehingga dapat disimpulkan bahwa model regresi yang terbentuk tidak mengalami gejala multikolinearitas, artinya tidak terdapat korelasi di antara variabel independen.

\section{Uji Heteroskedastisitas}

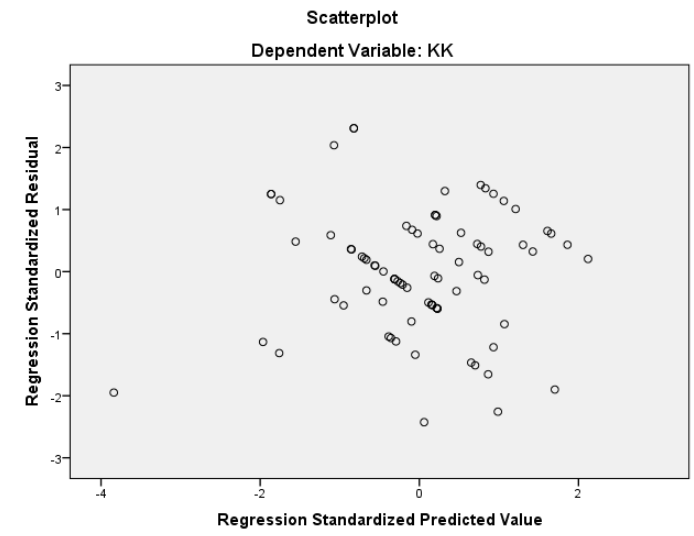

Gambar 4.2

Hasil Analisis Uji Heteroskedastisitas 
Pengujian heterokedastisitas pada penelitian ini menggunakan model scatterplot. Jika tidak ada pola yang jelas, serta titik-titik menyebar di atas dan dibawah angka 0 pada sumbu Y, maka tidak terjadi heteroskedastisitas. Dari hasil uji heterokedastisitas dengan menggunakan scatterplot menunjukkan bahwa semua titik tersebar secara acak dan tidak mengumpul di satu titik serta tidak membentuk suatu pola yang teratur. Maka dapat disimpulkan bahwa tidak terjadi heterokedastisitas pada model regresi.

\section{Hasil Pengujian Hipotesis}

Analisis Regresi Berganda

Model persamaan linier berganda yang digunakan adalah sebagai berikut :

$$
\mathrm{Y}=1.080+0.146 \mathrm{G}+\mathbf{0 . 2 6 6} \mathrm{KP}+\mathbf{0 . 3 8 1} \mathrm{BO}
$$

Keterangan:

Y : Kinerja Karyawan

$\mathrm{G}:$ : Gender

KP : Gaya Kepemimpinan

BO : Budaya Organisasi

Uji t

$\mathrm{H}_{\mathrm{a} 1}$ : Gender berpengaruh positif terhadap kinerja karyawan.

Hasil pengujian statistik dengan uji t menunjukkan nilai signifikansi sebesar 0,07. Nilai tersebut lebih besar daripada tingkat signifikansi yang ditentukan sebesar 0,05.

$\mathrm{H}_{\mathrm{a} 2}$ : Gaya kepemimpinan berpengaruh positif terhadap kinerja karyawan.

Hasil pengujian statistik dengan uji t menunjukkan nilai signifikansi sebesar 0,006. Nilai tersebut lebih kecil daripada tingkat signifikansi yang ditentukan sebesar 0,05.

$\mathrm{H}_{\mathrm{a} 3}$ : Budaya organisasi berpengaruh positif terhadap kinerja karyawan.

Hasil pengujian statistik dengan uji t menunjukkan nilai signifikansi sebesar 0,000. Nilai tersebut lebih kecil daripada tingkat signifikansi yang ditentukan sebesar 0,05.

\section{Uji F (ANOVA)}

Uji F menunjukkan apakah seluruh variabel independen memiliki pengaruh terhadap variabel dependen. Apabila nilai signifikansi dari uji F kurang dari 0.05 maka terdapat pengaruh variabel independen terhadap variabel dependen. Hasil kesimpulan dari pengujian ANOVA ini menunjukkan bahwa nilai signifikansi 0,00 lebih kecil signifikansi 0,05 (Sig. 0.00 $<0.05)$. Oleh karena itu dapat dinyatakan bahwa variabel independen yang terdiri dari gender $\left(\mathrm{X}_{1}\right)$, gaya kepemimpinan $\left(\mathrm{X}_{2}\right)$ dan budaya organisasi $\left(\mathrm{X}_{3}\right)$ memiliki pengaruh terhadap variabel dependen yaitu kinerja karyawan (Y).

\section{Uji Coeficient Multiple Determination (adjusted $\mathbf{R}^{\mathbf{2}}$ )}

Uji adjusted $\mathrm{R}^{2}$ digunakan untuk mengetahui seberapa besar model regresi berganda menerangkan variasi variabel dependen. Nilai adjusted $\mathrm{R}^{2}$ berkisar dari 0 sampai dengan 1 , semakin besar hasilnya berarti semakin besar kemampuan variabel dependen menerangkan variasi dari variabel dependen. Hasil kesimpulan dari uji Adjusted R Square menyatakan bahwa variasi variabel dependen (Kinerja Karyawan) dapat dijelaskan oleh variabel independen yang dipilih yaitu Gender, Gaya Kepemimpinan dan Budaya Organisasi sebesar 42.6\% sedangkan $57.4 \%$ dipengaruhi oleh variabel independen lainnya.

\section{KESIMPULAN}

Penelitian ini bertujuan untuk mengetahui apakah gender pemimpin, gaya kepemimpinan dan budaya organisasi berpengaruh terhadap kinerja karyawan di PT XYZ. Penelitian ini mengambil data dimulai dari bulan Juli 2016 sampai dengan Juli 2017. Berdasarkan hasil penelitian yang diolah dengan SPSS 20.0 dan pengambilan sampel berdasarkan kriteria yang telah ditetapkan, maka diperoleh kesimpulan sebagai berikut:

a. Gender pemimpin memiliki pengaruh yang positif namun tidak signifikan terhadap kinerja karyawan. Gender memiliki nilai signifikansi lebih besar dari 0,05 yakni sebesar 
0,070 yang menunjukkan bahwa variabel gender berpengaruh positif namun tidak signifikan terhadap kinerja karyawan.

b. Gaya Kepemimpinan berpengaruh positif dan signifikan terhadap kinerja karyawan. Gaya Kepemimpinan memiliki nilai signifikansi lebih kecil dari 0,05 yakni sebesar 0,006 yang menunjukkan bahwa variabel gaya kepemimpinan berpengaruh positif dan signifikan terhadap kinerja karyawan.

c. Budaya Organisasi berpengaruh positif dan signifikan terhadap kinerja karyawan. Budaya Organisasi memiliki nilai signifikansi lebih kecil dari 0,05 yakni sebesar 0,000 yang menunjukkan bahwa variabel Budaya Organisasi berpengaruh positif dan signifikan terhadap kinerja karyawan.

\section{DAFTAR PUSTAKA}

Andreson. (2015). Analisa Pengaruh Gaya Kepemimpinan, Komunikasi Internal dan Motivasi Kerja terhadap Kinerja Karyawan pada Divisi IT PT BCA, Tbk. Jakarta: Universitas Tarumanagara

Bass, B.M \& Avolio. (1990). The Implications of Transaksional and Transformational, Team and Organization Development, 4, 231- 273

Dessler, G. (2005). Manajemen Sumber Daya Manusia. Alih bahasa: Eli Tanya. Penyunting Bahasa: Budi Supriyanto. Jakarta: Indeks.

Ernawati. (2013). Analisis Pengaruh Kompensasi dan Kepemimpinan terhadap Kinerja Karyawan. Semarang: Universitas Diponegoro

Mangkunegara, A. P. (2002). Manajemen Sumber Daya Manusia. Bandung: Remaja Rosdakarya

Mangkunegara, A. P. (2008). Manajemen Sumber Daya Manusia Perusahaan (Edisi dari Teori ke Praktik). Bandung: Alfabeta.

Mas'ud, F. (2004). Survei Diagnosis Organisasional (Konsep dan Aplikasi). Semarang: Badan Penerbit Universitas Diponegoro.

Novianty, D. (2014). Musawa Journal of Gender Studies, 6(1).

Prawirosentono, S. (1999). Kebijakan Kinerja Karyawan. Yogyakarta: BPFE

Sabrina, E. \& Sari, S. A. (2013). Pengaruh Gender dan Gaya Kepemimpinan terhadap Karir Komitmen pada Karyawan Rumah Sakit Bumi Waras Bandar Lampung. Jakarta: Universitas Bina Nusantara

Tika, M. P. (2006). Budaya Organisasi dan Peningkatan Kinerja Perusahaan. Jakarta: Bumi Aksara

Widiastuti, T., et al. (2011). Jurnal Aplikasi Manajemen, 9(3).

Windasari, M. (2010). Persepsi Pegawai Bank Perempuan terhadap Promosi Jabatan Berkriteria Penampilan Modis. Medan: Universitas Sumatera Utara 